\title{
CORRIGENDUM
}

\section{The GDI-like solubilizing factor PDE $\delta$ sustains the spatial organization and signalling of Ras family proteins}

Anchal Chandra, Hernán E. Grecco, Venkat Pisupati, David Perera, Liam Cassidy, Ferdinandos Skoulidis, Shehab A. Ismail, Christian Hedberg, Michael Hanzal-Bayer, Ashok R. Venkitaraman, Alfred Wittinghofer and Philippe I. H. Bastiaens

Nat. Cell Biol. 14, 148-158 (2012); published online 18 December 2011; corrected after print 25 January 2012

In the version of this article initially published online and in print, the $y$-axis label for the graph in Figure $6 \mathrm{~b}$ was incorrect. The correct label for the axis is "Normalized Ras-GTP". This error has been corrected online in both the HTML and PDF versions of the article.

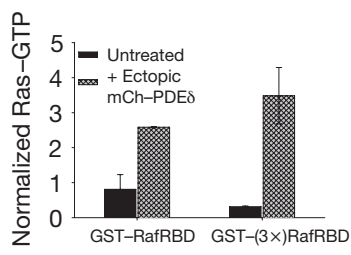

